\title{
Волоконный ВКР-лазер на основе двухсердцевинного световода с ВБР, записанными фемтосекундным излучением
}

\author{
С.Р. Абдуллина $^{1, *}$, М.И. Скворцов ${ }^{1,2}$, А.А. Вольф ${ }^{1,2}$, А.В. Достовалов ${ }^{1,2}$, И.А. Лобач ${ }^{1,2}$, \\ А.А. Власов ${ }^{1}$, С. Вабниц ${ }^{2,3}$, С.А. Бабин ${ }^{1,2}$ \\ ${ }^{1}$ Институт автоматики и электрометрии СО РАН, Новосибирск \\ ${ }^{2}$ Новосибирский государственньй университет \\ ${ }^{3}$ Университет Брешии, Брешиа, Италия \\ *E-mail: abdullina.sofia@gmail.com
}

DOI:10.31868/RFL2018.74-75

Лазеры на основе многосердцевинных волоконных световодов (МВC) являются перспективными высокомощными источниками, поскольку в случае распространения излучения по нескольким сердцевинам уменьшается плотность мощности, что приводит к уменьшению влияния ограничивающих мощность нелинейных эффектов. Важной задачей при реализации лазеров на основе МВС со слабой связью между сердцевинами является синхронизация фаз мод, распространяющихся в различных сердцевинах, для чего обычно используются внешние элементы $[1,2]$. В литературе можно найти достаточно большое число работ, посвященных лазерам на основе активных многосердцевинных волокон, при этом практически нет работ, посвященных лазерам на основе пассивных МВС. В работе [3] продемонстрирован ВКР-лазер на основе двухсердцевинного волоконного световода (ДВС) с сохранением поляризации длиной 550 м со случайной распределенной обратной связью (СРОС) за счет рэлеевского рассеяния. В качестве входного зеркала в конфигурации полуоткрытого резонатора использовалось кольцевое зеркало, приваренное к спектрально-селективному разветвителю. Спектральная ширина линии генерации данного лазера оказалась в 5 раз меньше, чем ширина линии случайного ВКР-лазера в такой же конфигурации на основе односердцевинного волокна. Показано, что сужение линии генерации обусловлено ослаблением нелинейных эффектов и спектрально-селективными свойствами участка ДВС из-за связи мод сердцевин (характерная длина перекачки составила 5-10 см). Другие схемы ВКР-лазеров на основе двух- и многосердцевинных световодов в литературе не описаны, между тем реализация и исследование характеристик как случайных, так и классических ВКР-лазеров на основе данного типа волокон представляет большой интерес. Конфигурации, описанные в данной работе, основаны на ДВС длиной 550 м аналогично [3]. Для формирования резонатора нами предложено использовать технологию поточечной фемтосекундной записи [4], позволяющую селективно записывать ВБР в одной или двух сердцевинах с высокой точностью позиционирования по трем координатам.

В работе представлен случайный ВКР-лазер на основе ДВС в конфигурации полуоткрытого резонатора, где роль входного зеркала выполняет высокоотражающая ВБР, записанная в одной из сердцевин, при этом накачка заводится в лазер через другую сердцевину, что позволяет избежать нерезонансных потерь. На выходе лазера выполнен косой скол. На Рис. 1 (a) приведены спектры генерации стоксовой компоненты при различных уровнях мощности. По сравнению с работой [3], получено улучшение стабильности генерации и сужение линии генерации стоксовой компоненты до 200 пм при максимальной выходной мощности ( $>3$ ВТ). 

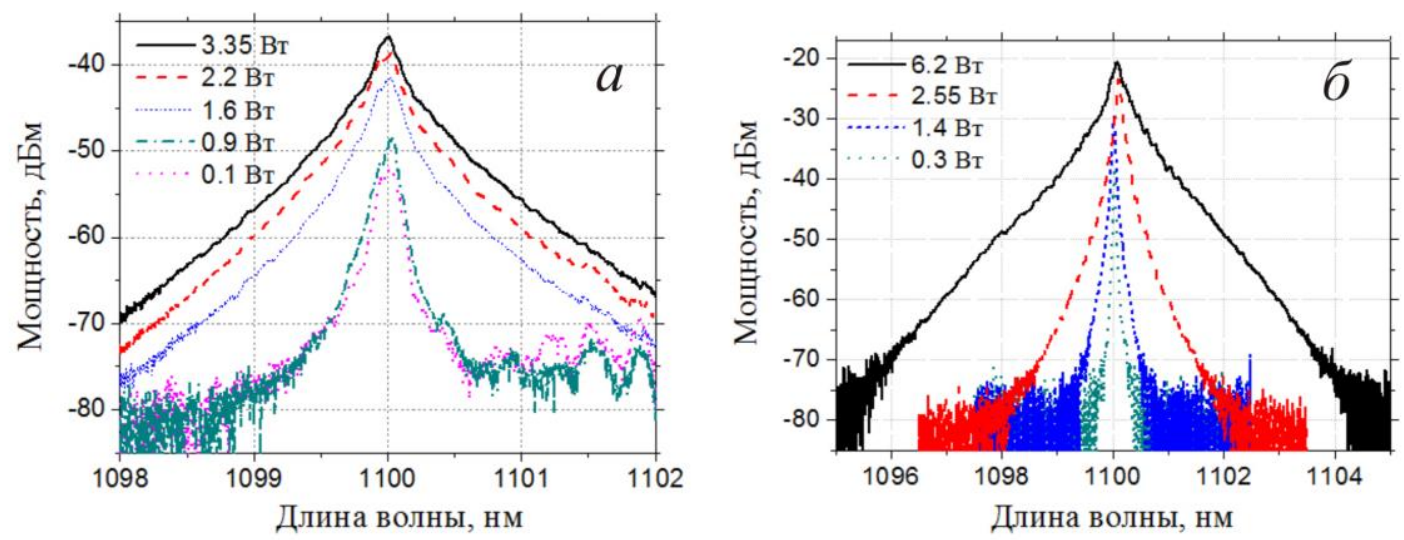

Рис. 1. Спектры генерации стоксовой компоненты при различных уровнях выходной мощности (a) для ВКР-лазера со СРОС; (б) для классического ВКР-лазера со слабоотражающей ВБР на выходе.

Также в работе реализованы классические конфигурации ВКР-лазеров на основе ДВС, где на входе в одной из сердцевин записана высокоотражающая ВБР аналогично СРОС ВКР-лазеру, а на выходном конце лазера выполнен прямой скол либо записана слабоотражающая ВБР. Коэффициент отражения выходной ВБР оптимизировался по результатам численного моделирования при решении системы балансных уравнений для мощностей накачки и стоксовой компоненты. На Рис. 1 (б) представлены спектры генерации стоксовой компоненты при различных уровнях мощности для конфигурации с выходной ВБР, эффективный коэффициент отражения которой оценивается как 15\%. Максимальная ширина линии генерации составила 140 пм при мощности генерации 6.2 Вт, что значительно ниже ширины линии генерации в классической конфигурации ВКР-лазера на основе ДВС той же длины с кольцевым зеркалом на входе и прямым сколом на выходе.

Кроме того, в работе предложен метод дополнительной спектральной фильтрации посредством записи на входе резонатора двух высокоотражающих ВБР в разных сердцевинах со смещением вдоль волокна, что приводит к образованию интерферометра Майкельсона.

В докладе будет представлен сравнительный анализ спектральных и мощностных характеристик случайных и классических ВКР-лазеров на основе ДВС в различных конфигурациях, реализованных с помощью техники поточечной фемтосекундной записи.

Работа выполнена при финансовой поддержке Министерства науки и высшего образования РФ, грант 14.Y26.31.0017 (в части разработки технологии записи ВБР в многосердцевинных световодах) и грантом РНФ 14-22-00118 (в части исследования ВКР-генерации).

\section{Литература}

[1] M. Wrage, P. Glas et al. Opt. Lett. 25, 1436-1438 (2000).

[2] A.S. Kurkov, V.M. Paramonov et al Laser Phys. Lett. 3, 441-444 (2006).

[3] A. E. Budarnykh, I. A. Lobach et al Opt. Lett. 43, 567-570 (2018).

[4] A.V. Dostovalov, A.A. Wolf et al Opt. Exp. 24 16232-16237 (2016). 